\title{
The role of mycorrhizal associations in plant potassium nutrition
}

\author{
Kevin Garcia ${ }^{\dagger}$ and Sabine D. Zimmermann* \\ Biochimie et Physiologie Moléculaire des Plantes, UMR 5004 CNRS/INRA/SupAgro/UM2, Montpellier, France
}

Edited by:

Daniel Wipf, Burgundy University,

France

Reviewed by:

Iver Jakobsen, Technical University

of Denmark, Denmark

Pierre-Emmanuel Courty, University

of Basel - Botanical Institute,

Switzerland

*Correspondence:

Sabine D. Zimmermann, Biochimie et Physiologie Moléculaire des

Plantes, UMR 5004

CNRS/INRA/SupAgro/UM2, Place

Viala, Campus

INRA-SupAgro-UM2-CNRS,

Montpellier, France

e-mail: sabine.zimmermann@

supagro.inra.fr

${ }^{\dagger}$ Present address:

Kevin Garcia, Department of

Agronomy, University of

Wisconsin-Madison, Madison, USA
Potassium $\left(\mathrm{K}^{+}\right)$is one of the most abundant elements of soil composition but it's very low availability limits plant growth and productivity of ecosystems. Because this cation participates in many biological processes, its constitutive uptake from soil solution is crucial for the plant cell machinery. Thus, the understanding of strategies responsible of $\mathrm{K}^{+}$nutrition is a major issue in plant science. Mycorrhizal associations occurring between roots and hyphae of underground fungi improve hydro-mineral nutrition of the majority of terrestrial plants. The contribution of this mutualistic symbiosis to the enhancement of plant $\mathrm{K}^{+}$nutrition is not well understood and poorly studied so far. This mini-review examines the current knowledge about the impact of both arbuscular mycorrhizal and ectomycorrhizal symbioses on the transfer of $\mathrm{K}^{+}$from the soil to the plants. A model summarizing plant and fungal transport systems identified and hypothetically involved in $\mathrm{K}^{+}$transport is proposed. In addition, some data related to benefits for plants provided by the improvement of $\mathrm{K}^{+}$nutrition thanks to mycorrhizal symbioses are presented.

Keywords: potassium, plant nutrition, arbuscular mycorrhizal symbiosis, ectomycorrhizal symbiosis, transport systems

\section{INTRODUCTION}

Potassium $\left(\mathrm{K}^{+}\right)$is one of the most important macronutrient for all organisms. In plants, $\mathrm{K}^{+}$represents $2-10 \%$ of the dry biomass, its optimal cytoplasmic concentration for enzyme activities being around 100-200 mM (Leigh and Wyn Jones, 1984). This cation participates to various crucial processes such as plasma membrane polarization, growth, stomatal aperture, or adaptation to environmental changes (Broadley and White, 2005; Wang and Wu, 2013; Anschütz et al., 2014; Shabala and Pottosin, 2014). Maintaining an elevated $\mathrm{K}^{+}$concentration in plant cells is vital for the smooth running of such physiological processes (Benito et al., 2014; Shin and Adams, 2014). Although $\mathrm{K}^{+}$ions are extremely abundant in soil, their availability is very low due to their strong mineral adsorption. Depending on soil type, the $\mathrm{K}^{+}$concentration in soil solution is approximately $0.1-1 \mathrm{mM}$ (Asher and Ozanne, 1967). This low availability combined to the constitutive demand of plants lead to the formation of depletion areas around roots (Drew and Nye, 1969). Consequently, plants need to develop efficient strategies to improve the $\mathrm{K}^{+}$uptake from soil (Nieves-Cordones et al., 2014; Zörb et al., 2014), such as the acquisition of high-affinity transport systems or the establishment of plant-microbe associations.

Mycorrhizal symbioses are mutualistic interactions between the root systems of around $80 \%$ of land plants and the mycelium of various fungi (Wang and Qiu, 2006). Among mycorrhizal associations, two forms are mainly studied due to their ecological importance, arbuscular mycorrhizae (AM) and ectomycorrhizae (ECM). Mycorrhizal fungi participate actively to plant development (Smith and Read, 2008) by improvement of access to nutrients, particularly when resources become scarce. In turn, vegetal partners provide up to $20-25 \%$ of photosynthetic carbohydrates to their symbionts (López et al., 2008). The improvement of plant nutrition through mycorrhizal symbioses and the molecular bases of nutrient transfer are currently well studied for phosphorus (Javot et al., 2007; Plassard and Dell, 2010) and nitrogen (Müller et al., 2007; Jin et al., 2012). However, only few data concern the possible mycorrhizal contribution to $\mathrm{K}^{+}$acquisition (Benito and Gonzalez-Guerrero, 2014).

Herewith, we compiled and summarized the current knowledge concerning the role of AM and ECM symbioses in plant $\mathrm{K}^{+}$nutrition. An overview of transport systems acting putatively in transfer of $\mathrm{K}^{+}$from soil to fungal cells and from fungi to plant cells is highlighted. Finally, improvement of $\mathrm{K}^{+}$acquisition by mycorrhizal associations will lead to benefits for the plant in diverse environmental conditions.

\section{EVIDENCE OF PLANT POTASSIUM NUTRITION BY MYCORRHIZAL SYMBIOSIS \\ ARBUSCULAR MYCORRHIZAL SYMBIOSIS}

Plant $\mathrm{K}^{+}$nutrition through the arbuscular mycorrhizal pathway has been rarely studied. However, assessment of potassium distribution in AM fungi (Rhizophagus irregularis) using 
particle-induced X-ray emission (PIXE) experiments (Johansson and Campbell, 1988) revealed a strong $\mathrm{K}^{+}$accumulation in spores (Pallon et al., 2007), hyphae (Olsson et al., 2008), and vesicles (Olsson et al., 2011). Interestingly, PIXE analyses showed a higher $\mathrm{K}^{+}$concentration in root-sections of Aster tripolium mycorrhized by $R$. irregularis than non-inoculated plants, suggesting a possible increase of $\mathrm{K}^{+}$acquisition due to the AM colonization (Scheloske et al., 2004). Such a $\mathrm{K}^{+}$enrichment of plants mycorrhized by various AM fungi was also observed in Zea mays root steles (Kaldorf et al., 1999), in Pelargonium peltatum shoots (Perner et al., 2007) and in Lactuca sativa leaves (Baslam et al., 2013). $\mathrm{K}^{+}$transport was commonly visualized by the utilization of rubidium $\left(\mathrm{Rb}^{+}\right)$as an analog tracer. Measuring AM fungi mediated $\mathrm{Rb}^{+}$uptake from the soil, Hawkes and Casper (2002) showed putative competition mechanisms for four herbaceous species.

\section{ECTOMYCORRHIZAL SYMBIOSIS}

Potassium fluxes from ECM fungi to host plants were first observed by determination of $\mathrm{Rb}^{+}$contents (Rygiewicz and Bledsoe, 1984; Jongbloed et al., 1991). Quantification of $\mathrm{K}^{+}$in Picea abies cultivated in a medium with $230 \mu \mathrm{M}$ of $\mathrm{K}^{+}$resulted in around $5-6 \%$ of total $\mathrm{K}^{+}$that came from the ECM fungus Paxillus involutus (Jentschke et al., 2001). Regarding the cellular distribution of $\mathrm{K}^{+}$within fungal hyphae, X-ray microanalysis showed localization mainly in vacuoles of the ECM fungus Pisolithus tinctorius (Orlovich and Ashford, 1993; Ashford et al., 1999). PIXE experiments on P. sylvestris / Suillus luteus mycorrhizae revealed a high $\mathrm{K}^{+}$concentration in ectomycorrhizae vascular tissues (Turnau et al., 2001). Excitingly, data obtained in multiple Rhizopogon sp. isolates from field showed an important $\mathrm{K}^{+}$sequestration in rhizomorphs, that could be vital for forests subjected to long periods of $\mathrm{K}^{+}$deprivation (Wallander et al., 2002; Wallander and Pallon, 2005). Another fungus that can be considered as an important $\mathrm{K}^{+}$accumulator is Suillus granulatus (Wallander et al., 2003). Strong mineral degradation capacities of these two latter ECM fungi were suggested by the identification of calcium-rich crystals originating from $\mathrm{K}^{+}$-rich mineral apatite on rhizomorph surfaces. Thus, Rhizopogon sp. and S. granulatus could be considered as key facilitators between soil and trees for $\mathrm{K}^{+}$fluxes in temperate forest ecosystems. Recently, an increase of $\mathrm{K}^{+}$contents of about $35 \%$ was observed in Pinus pinaster mycorrhized by Hebeloma cylindrosporum upon 2 months culturing in $\mathrm{K}^{+}$deficiency, suggesting that this fungus plays a crucial role in pine adaptation to limiting conditions (Garcia et al., 2014). $\mathrm{K}^{+}$assimilation was improved also in shoots of Acacia spirorbis and Eucalyptus globules mycorrhized by Pisolithus albus up to 38\% (Jourand et al., 2014). By contrast, Quercus ilex and Quercus faginea colonized by Tuber melanosporum displayed a significant reduction of $\mathrm{K}^{+}$concentrations (Dominguez Nunez et al., 2006). However, in another experiment, no difference in $\mathrm{K}^{+}$contents was observed between control plants of Pinus halepensis, Q. faginea, and Quercus petraea, and those inoculated with T. melanosporum (Dominguez Nunez et al., 2008). These contradictory data highlighted once again that $\mathrm{K}^{+}$allocation from soil to plants through ECM fungi need complementary functional investigations.

\section{TRANSPORT OF POTASSIUM IN MYCORRHIZAL INTERACTIONS TRANSPORT SYSTEMS ON THE FUNGAL SIDE}

Recent access to genomes of ECM fungi Laccaria bicolor (Martin et al., 2008), T. melanosporum (Martin et al., 2010) and many others (http://genome.jgi.doe.gov/Mycorrhizal_fungi/Mycorrhizal_ fungi.info.html) allows the identification of new candidate genes involved in mycorrhizal resource exchanges (Casieri et al., 2013). Consequently, four families of putative $\mathrm{K}^{+}$transport systems could be identified in ECM fungi (Figure 1) on the basis of their homology to yeast Trk transporters (Ko and Gaber, 1991), to yeast TOK channels (Ketchum et al., 1995), to bacterial and yeast KT/KUP/HAK transporters (Bossemeyer et al., 1989; Bañuelos et al., 1995) and to animal Shaker-like channels (SKC) (Papazian et al., 1987; Jan and Jan, 1997). Before availability of these genomes, a Trk-type transporter and a Shaker-like channel were identified in an EST library of H. cylindrosporum (Lambilliotte et al., 2004). The member of the Trk/Ktr/HKT family (CorratgéFaillie et al., 2010) was functionally characterized. $H c$ Trk1 was shown to restore partially the wild-type phenotype of a yeast strain deficient in $\mathrm{K}^{+}$uptake (Corratgé et al., 2007). Moreover, electrophysiological analyses performed by expression of cRNA in Xenopus oocytes argued that $H c$ Trk1 might function as a $\mathrm{Na}^{+}-\mathrm{K}^{+}$ transporter. More recently, the use of $H$. cylindrosporum transgenic lines allowed the localization of this transporter exclusively in external hyphae of P. pinaster mycorrhizae (Garcia et al., 2014), suggesting a specialized reorganization of $H c$ Trk1 to uptake sites. The other candidate identified in the H. cylindrosporum EST library belongs to the SKC family representing voltage-dependent $\mathrm{K}^{+}$-selective channels (Lambilliotte et al., 2004). Interestingly, SKC channels were found exclusively in Basidiomycota fungi and in some members of basal fungi, whereas they are absent in sequenced Ascomycota, suggesting a loss of these $\mathrm{K}^{+}$channels in this clade. Excitingly, the H. cylindrosporum genome accession provides now two additional types of transport systems, three $\mathrm{HcTOK}$ channels and a $\mathrm{HcHAK}$ transporter. The analysis of these new candidates is currently in progress in order to dissect the whole $\mathrm{K}^{+}$transportome of $H$. cylindrosporum.

Transporters and channels of AM fungi are still the missing part of the $\mathrm{K}^{+}$transport from soil to host. Four sequences of $R$. irregularis from an EST library (http://mycor.nancy.inra. fr/IMGC/GlomusGenome/index3.html) were identified as $\mathrm{K}^{+}$ transport systems (Casieri et al., 2013). Three of them are coding for SKC-type channels and one for a KT/KUP/HAK transporter. Interestingly, no Trk and TOK members were identified from this library, and even from the sequenced nuclear genome (http://genome.jgi.doe.gov/Gloin1/Gloin1.home.html). Functional characterization and analysis of these new candidates will provide more precise information on fungal molecular players involved in $\mathrm{AM}$ plant $\mathrm{K}^{+}$nutrition.

Future research on AM and ECM K ${ }^{+}$transport systems need to precise their putative involvement in $\mathrm{K}^{+}$uptake from the soil or in $\mathrm{K}^{+}$release toward plant cells. Based on homology, it is tempting to argue that transporters of the $\operatorname{Trk} / \mathrm{Ktr} / \mathrm{HKT}$ and KT/KUP/HAK families could take up $\mathrm{K}^{+}$from the soil. Similarly, Shaker-like $\mathrm{K}^{+}$and TOK channels could be probably involved in the transfer of $\mathrm{K}^{+}$from the arbuscule or Hartig net to 
A

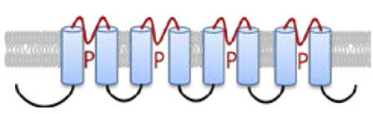

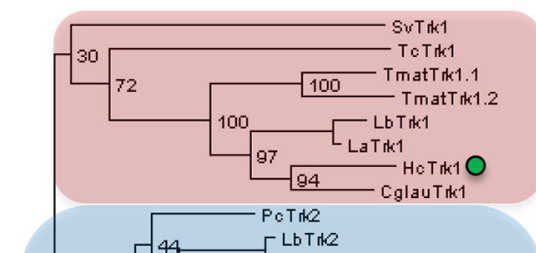

[ LbTh2

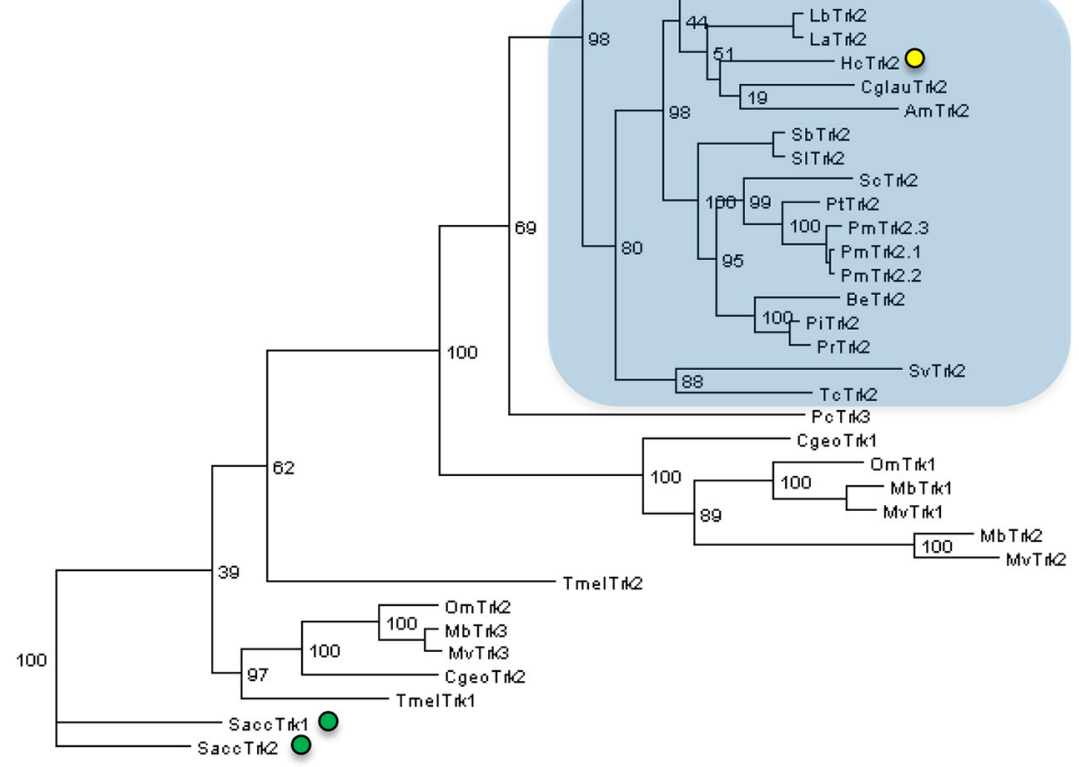

Trk1 sub-family

5
0
है
है
$\frac{0}{5}$
पे
0

Trk2 sub-family

B
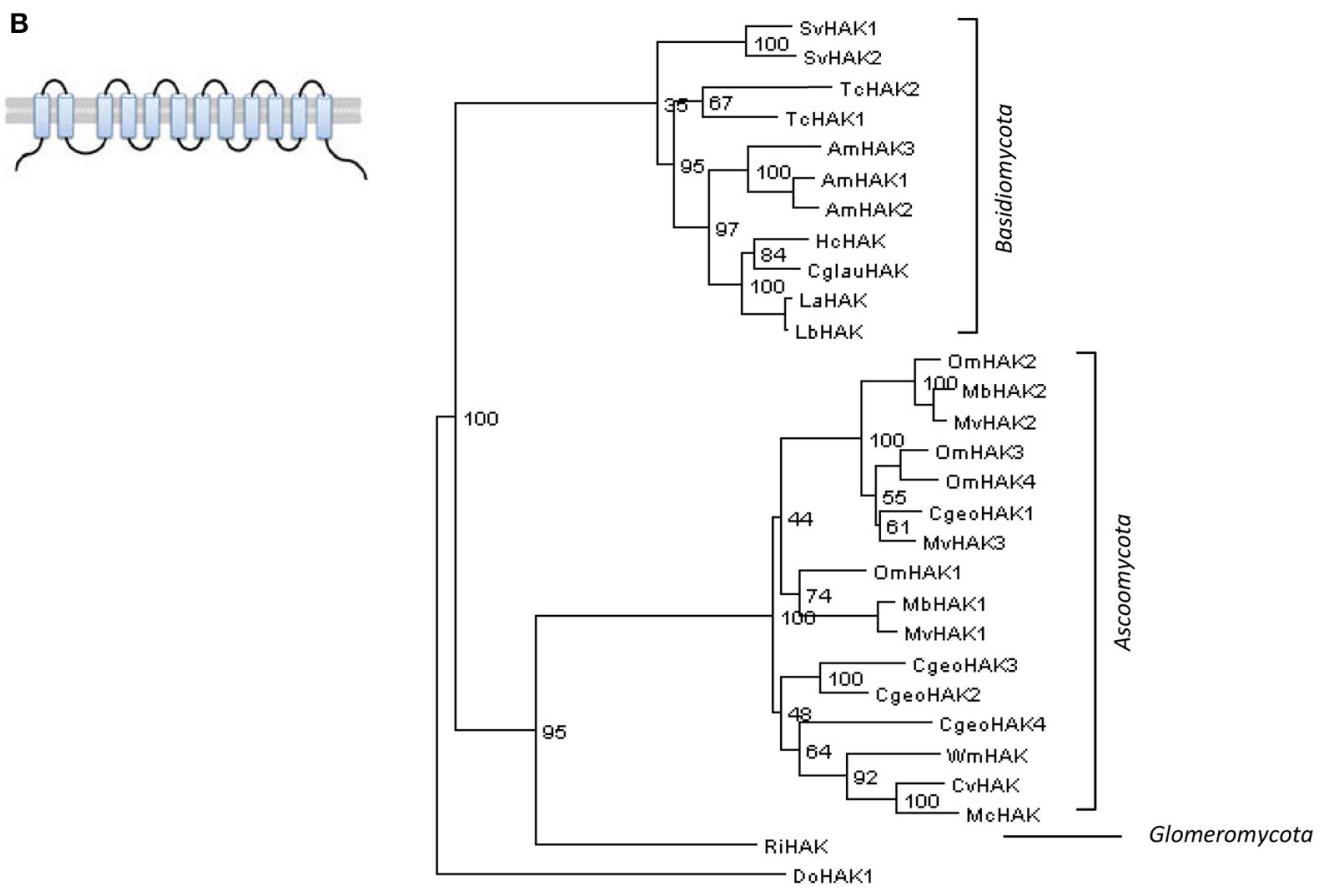

FIGURE 1 | Continued 

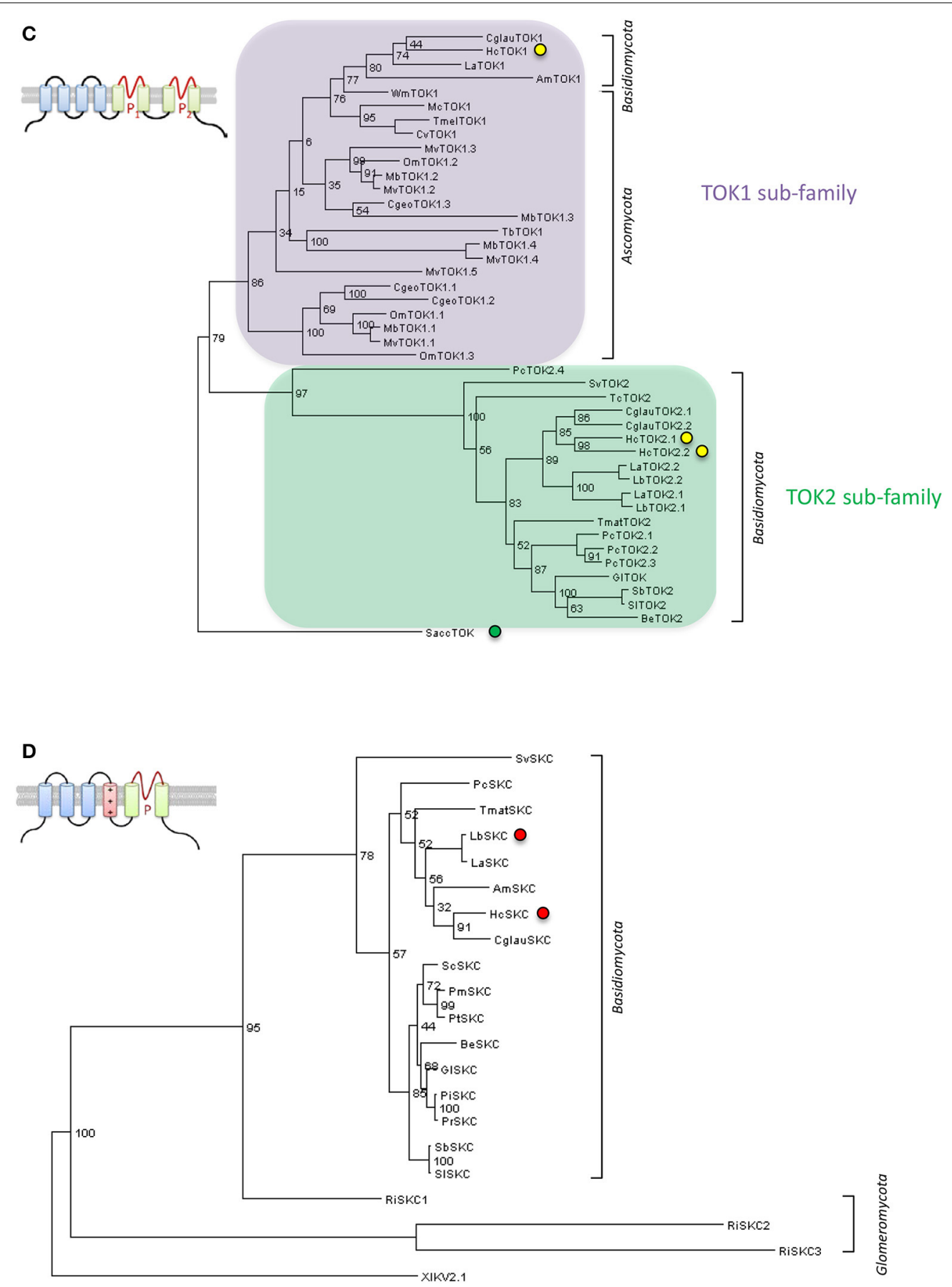

FIGURE 1 | Phylogenetic trees of potassium transport systems from sequenced mycorrhizal fungi. Four families of $\mathrm{K}^{+}$transport systems were identified in sequenced mycorrhizal fungi. Two of them code for putative transporters, for the (A) Trk and (B) HAK families, and the two others for putative ion channels, for the (C) TOK and (D) Shaker-like (SKC) families, respectively. (A) Two sub-families of Trk transporters were identified in Basidiomycota. (C) Two subfamilies of TOK channels were found in Asco- and Basidiomycota. Neither of these two families were identified in the Glomeromycota species Rhizophagus irregularis. (D) No SKC channel was found in Ascomycota fungi (mycorrhizal or not), suggesting the loss of this channel in this clade. Structure models of each family are represented. Transmembrane domains are symbolized by rectangles and pore domains by a $\mathrm{P}$. The voltage-dependent domain of SKC proteins (D) is indicated by a red rectangle $(+++)$. Trees were constructed using maximum likelihood method with 100 bootstraps. Green, yellow and red circles indicate successful published, successful unpublished (Zimmermann et al., unpublished data) or failed unpublished functional characterization, respectively. Am, Amanita muscaria; Be, Boletus eludis; Cgeo, Cenococcum geophilum; Cglau, Cortinarius glaucopus; Cv, Choiromyces venosus; Hc, Hebeloma cylindrosporum; GI, Gyrodon lividus; La, Laccaria amethystina; Lb, Laccaria bicolor; Mb, Meliniomyces bicolor; Mc, Morchella conica; Mv, Meliniomyces variabilis; Om, Oidiodendron maius; Pc, Piloderma croceum; Pi, Paxillus involutus; Pm, Pisolithus microcarpus; Pr, Paxillus rubicundulus; Pt, Pisolithus tinctorius; Ri, Rhizophagus irregularis; Sb, Suillus brevipes; Sc, Scleroderma citrinum; SI, Suillus luteus; Sv, Sebacina vermifera; Tb, Terfezia boudieri; Tc, Tulasnella calospora; Tmat, Tricholoma

(Continued) 


\section{FIGURE 1 | Continued}

matsutake; Tmel, Tuber melanosporum; Wm, Wilcoxina mikolae. Lengths of aligned sequences are around 1000, 800, 900, and 500 amino acids for Trk, KUP, TOK, and SKC proteins,

respectively. Saccharomyces cerevisiae [SaccTrk1 and SaccTrk2 (A)
SaccTOK (C)], Debaryomyces occidentalis [DoHAK1 (B) and Xenopus laevis XIKV2.1 (D)] protein sequences were selected as outgroups to root trees. All sequences were picked up on the mycorrhizal fungi JGI genome portal: http://genome.jgi.doe.gov/ Mycorrhizal_fungi/Mycorrhizal_fungi.info.html. host plant cortical cells (Figure 2; Benito and Gonzalez-Guerrero, 2014). However, caution must be taken on these predictions due to the possible bidirectional behavior of some transport systems in specific conditions and due to their unknown subcellular localization.

\section{TRANSPORT SYSTEMS ON THE PLANT SIDE}

The direct pathway of woody plant $\mathrm{K}^{+}$uptake (Figure 2A) is poorly studied so far in contrast to model plants as, e.g., Arabidopsis thaliana (Alemán et al., 2011; Dreyer and Uozumi, 2011; Coskun et al., 2014; Nieves-Cordones et al., 2014). However, some $\mathrm{K}^{+}$transport systems in woody plants able to form ECM associations have been identified. For example, two channels expressed in roots of Populus euphratica (PeKC1 and PeKC2) were characterized (Zhang et al., 2010). Interestingly, their over-expression led to complementation of the A. thaliana akt1 mutant. Because AKT1 is involved in $\mathrm{K}^{+}$acquisition in A. thaliana (Hirsch et al., 1998), this finding strongly suggests that these two transport systems could play a role in $\mathrm{K}^{+}$nutrition in poplar trees. However, their role in context of mycorrhizal associations has not been dissected. Their expression analysis upon AM and ECM symbioses would be a good starting point for the identification of transport systems required in $\mathrm{K}^{+}$nutrition, as already shown for phosphate transporters of Populus trichocarpa (LothPereda et al., 2011). In turn, in AM plants, the direct pathway of $\mathrm{K}^{+}$uptake is well known since many years (Figure 2B), several transport systems were identified, functionally characterized and their role in $\mathrm{K}^{+}$nutrition in various conditions was investigated. These proteins belong to the transporter families Trk/Ktr/HKT (Corratgé-Faillie et al., 2010) and KT/KUP/HAK (Grabov, 2007), as well to the Shaker-like channels (Dreyer and Uozumi, 2011).

Very few studies investigated so far the plant $\mathrm{K}^{+}$transportome of the mycorrhizal pathway (Figures 2C,D). Recently two ESTs of P. sylvestris representing the SKOR-type outward Shaker-like channel were found to be highly up-regulated during ECM interaction with Ceonococcum geophilum, and less up-regulated upon interaction with S. granulatus and Rhizopogon roseolus (Martina Peter, pers. comm.). A KT/KUP/HAK transporter was found to be 44-fold up-regulated in Lotus japonicus mycorrhized by the AM fungus Gigaspora margarita (Guether et al., 2009). More recently, a SKOR channel of $Z$. mays was identified to be up-regulated by AM colonization in response to salinity (Estrada et al., 2013). Future analyses of these first plant candidates are needed to dissect the molecular bases of $\mathrm{K}^{+}$uptake from the plant-fungus interface.

\section{BENEFITS OF MYCORRHIZAL POTASSIUM UPTAKE FOR PLANTS IMPROVEMENT OF SALT AND DROUGHT STRESS TOLERANCE}

Advantages conferred by $\mathrm{K}^{+}$originating from mycorrhizae include improved stress tolerance of the host plant. Acquisition of plant salinity tolerance by AM symbiosis has been described for several decades (Hirrel and Gerdemann, 1980; Ojala et al., 1983), very little is known about physiological and molecular mechanisms enhancing this adaptation. AM colonization enhances the plant $\mathrm{K}^{+}$uptake whereas the $\mathrm{Na}^{+}$content is maintained at low levels in salt stress conditions applied to Vicia faba (Rabie and Almadini, 2005), Acacia nilotica (Giri et al., 2007), Ocimum basilicum (Zuccarini and Okurowska, 2008), Glycine max (Sharifi et al., 2007), Olea europaea (Porras-Soriano et al., 2009), or Z. mays (Estrada et al., 2013). These data indicate that AM symbiosis improves salt tolerance of the host plant through the modification of the $\mathrm{K}^{+} / \mathrm{Na}^{+}$balance. This finding was corroborated by high internal $\mathrm{K}^{+}$concentrations in several AM fungi collected in natural saline sites (Hammer et al., 2011a). Recently, Estrada et al. (2013) demonstrated differential expression levels during AM colonization for three $\mathrm{K}^{+}$transport systems of $Z$. mays putatively involved in phloem loading/unloading ( $Z m$ AKT2), xylem release $(Z m S K O R)$, and $\mathrm{Na}^{+} / \mathrm{K}^{+}$homeostasis ( $\left.Z m S O S 1\right)$. These exciting findings open the way to the elucidation of plant proteins involved in transport of $\mathrm{K}^{+}$originating from mycorrhizal fungi, especially under salt stress conditions.

Input of AM symbiosis on drought stress resistance of plants has been well studied (Harley and Smith, 1983; Al-Karaki, 1998; Porcel and Ruiz-Lozano, 2004). Improvement in hydric stress tolerance is accompanied by an elevation of $\mathrm{K}^{+}$concentrations observed, e.g., in Citrus tangerine (Wu and Xia, 2006), indicating a role of AM symbiosis through $\mathrm{K}^{+}$uptake required for osmotic adjustment. Interestingly, El-Mesbahi et al. (2012) demonstrated that hydraulic conductivity of AM-colonized $Z$. mays growing under hydric stress was enhanced by supply of $\mathrm{K}^{+}$in external medium. Moreover, the expression level of the plant aquaporin $Z m$ PIP2;6 was modulated by $\mathrm{K}^{+}$supply in hydric stress, suggesting a tight link between adaptation of mycorrhized plants to drought stress and $\mathrm{K}^{+}$resource availability.

Salt and drought stress tolerance linked to potassium nutrition has been so far less studied in ECM plants. However, recently, Danielsen and Polle (in press) have been shown an increase of $\mathrm{K}^{+}$ in ECM poplar under drought conditions suggesting also in this symbiotic interaction a role of mycorrhizal $\mathrm{K}^{+}$for environmental stress adaptation.

\section{INTERACTION BETWEEN PLANT POTASSIUM AND PHOSPHORUS NUTRITION}

Interestingly, a strong correlation between $\mathrm{K}^{+}$and phosphorus (P) during AM symbiosis was reported. Olsson et al. $(2008,2011)$ highlighted a co-distribution and a linked ratio of $\mathrm{K}^{+}$and $\mathrm{P}$ in $R$. irregularis spores, hyphae and vesicles. When spores were enriched in $\mathrm{P}$, an increase of $\mathrm{K}^{+}$content was observed (Olsson et al., 2011). Several studies on ECM symbiosis reported similar results. Indeed, a strong correlation in $\mathrm{K}^{+}$and $\mathrm{P}$ distribution 


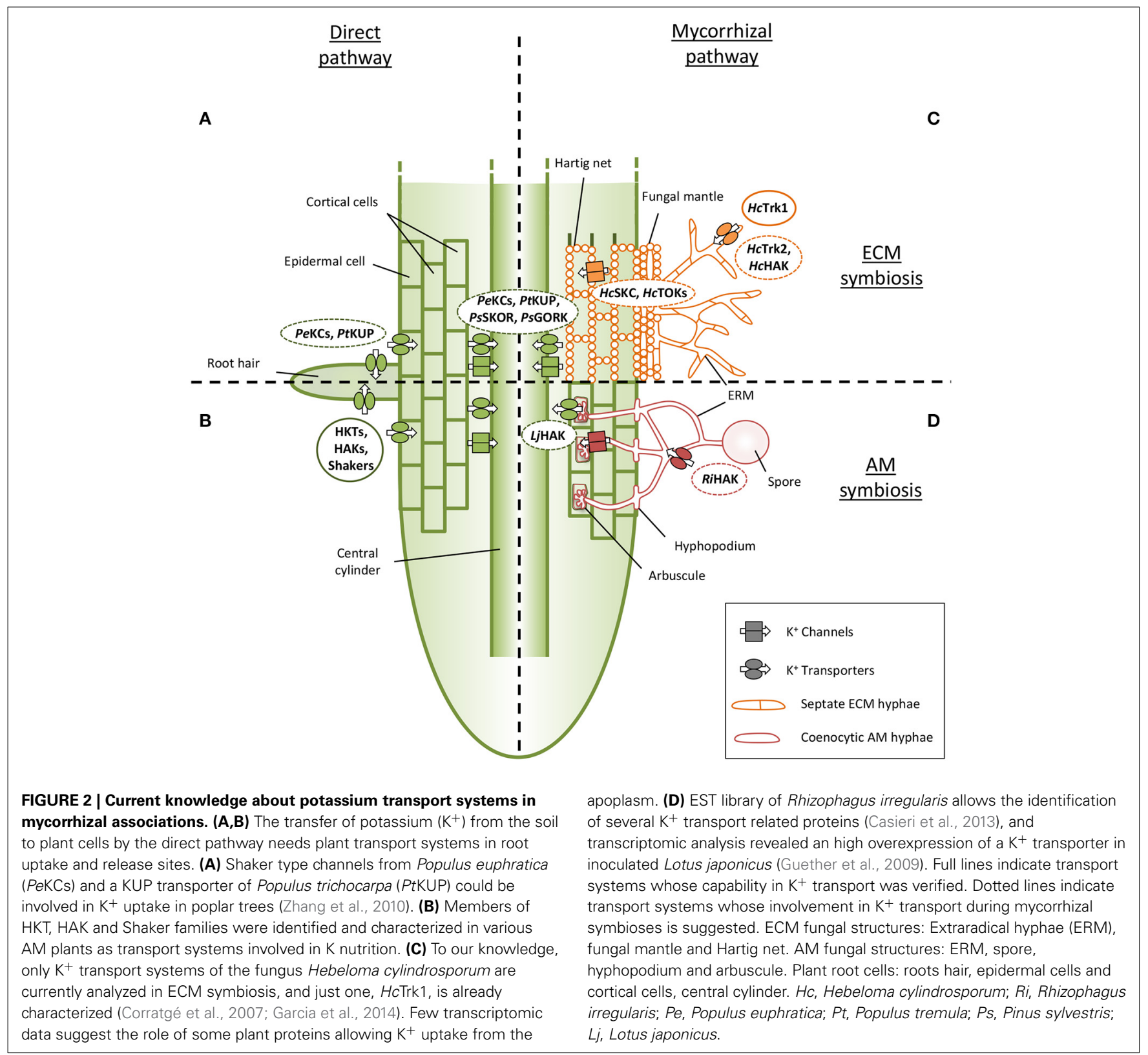

was described in rhizomorphs of Rhizopogon sp. using PIXE analyses (Wallander and Pallon, 2005). Other studies showed that the decrease of $\mathrm{P}$ availability in soil could lead to either a decrease or an increase of $\mathrm{K}^{+}$content in ECM with Pinus rigida (Cumming, 1993) or in AM with Trifolium subterraneum (Smith et al., 1981), respectively. Moreover, $\mathrm{K}^{+}$and $\mathrm{P}$ were found in same fungal compartments of $P$. involutus such as vacuoles (Orlovich and Ashford, 1993; Ashford et al., 1999). Interestingly, it is assumed that $\mathrm{K}^{+}$is one of the major counter-ions of polyphosphate (polyP) granules, especially of soluble polyP short-chains mainly located in fungal vacuoles (Bücking and Heyser, 1999). Recently, elemental analysis of spherical electron-opaque granules in the vacuoles of Scleroderma verrucosum hyphae associated with Quercus acutissima using TEM-EDS (Transmission electron microscopy-energy-dispersive Xray Spectroscopy) showed major correlated peaks for P and K (Jung and Tamai, 2013). In addition, we have revealed recently that the over-expression of a $\mathrm{K}^{+}$ transporter of $\mathrm{H}$. cylindrosporum led to an alteration of $\mathrm{K}^{+}$and $\mathrm{P}$ translocation from roots to shoots of mycorrhized P. pinaster under $\mathrm{K}^{+}$deprivation (Garcia et al., 2014), providing new evidences for $\mathrm{K}^{+}$and $\mathrm{P}$ interaction during their transport in ECM symbiosis. All these data demonstrating the strong link between these two elements suggest that $\mathrm{K}^{+}$seems to be a more important component of mycorrhizal symbiosis than formerly suspected. Therefore, $\mathrm{K}^{+}$needs to be considered not only as a direct trophic element involved in plant $\mathrm{K}^{+}$nutrition, but also as an "indirect-trophic" component required for homeostasis and correct transfer of other nutrients to the host plant, such as inorganic phosphate. Moreover, Hammer et al. (2011b) described a $\mathrm{K}^{+}$ accumulation in an $\mathrm{AM}$ fungus related to low $\mathrm{C}$ supply from the 
plant. Consequently, we can imagine that in conditions of low availability of $\mathrm{C}$ originating from the host plant, the high concentration of $\mathrm{K}^{+}$observed in the fungus could be related to the accumulation of $\mathrm{P}$ (in polyP form) which is not transferred to the plant. However, additional investigations are needed to validate or not this hypothesis and to get more insight on the interaction occurring between $\mathrm{K}^{+}, \mathrm{P}$ and $\mathrm{C}$ in mycorrhizal symbioses.

\section{PROTECTION AGAINST RADIOCAESIUM POLLUTION}

Radiocaesium isotopes $\left({ }^{134} \mathrm{Cs},{ }^{137} \mathrm{Cs}\right)$ are important soil contaminants that can enter the food chain by the intermediate of plant uptake (Delvaux et al., 2001). It is well known that external $\mathrm{K}^{+}$ affects the acquisition of radiocaesium by plants (Tamponnet et al., 2008). Involvement of mycorrhizal symbiosis on radiocaesium uptake was reported. Evaluation of the $\mathrm{Cs}^{+} / \mathrm{K}^{+}$ratio in $P$. abies showed a lower acquisition of ${ }^{134} \mathrm{Cs}$ by plants inoculated with Hebeloma crustuliniforme due to its retention in the outer hyphae and to a better transfer of $\mathrm{K}^{+}$to the plant (Brunner et al., 1996). By contrast, P. pinaster mycorrhized by $R$. roseolus displayed more elevated concentrations in ${ }^{134} \mathrm{Cs}$ than non-mycorrhized plants, whereas the $\mathrm{K}^{+}$content remained stable (Ladeyn et al., 2008), highlighting the importance of the considered host-symbiont couple. The influence of $\mathrm{K}^{+}$on ${ }^{134} \mathrm{Cs}$ accumulation was also investigated in AM symbiosis, in Medicago truncatula colonized by $R$. irregularis. Radiocaesium accumulation of plants seems to be inversely correlated to $\mathrm{K}^{+}$contents in the external medium (Gyuricza et al., 2010a). Based on these results, $\mathrm{AM}$ symbiosis combined with high $\mathrm{K}^{+}$concentrations in external medium would be crucial to avoid ${ }^{134} \mathrm{Cs}$ accumulation in plants growing on contaminated soil. Interestingly, external $\mathrm{P}$ elicits the same effects as $\mathrm{K}^{+}$on ${ }^{134} \mathrm{Cs}$ uptake during AM colonization of M. truncatula (Gyuricza et al., 2010b), reinforcing the idea of a close relationship between $\mathrm{K}^{+}$and $\mathrm{P}$ via polyP synthesis, storage and transport. In contrast to these studies, pot experiments by Joner et al. (2004) with different external $\mathrm{K}^{+}$ concentrations, three host plants and two AM fungal species indicated that AM effects on plant ${ }^{134} \mathrm{Cs}$ and ${ }^{137} \mathrm{Cs}$ accumulation could be negligible. Further investigations will be needed to conclude whether mycorrhizal associations play a direct, via transport processes, or an indirect role on plant protection to radiocaesium contaminated soils.

\section{CONCLUSION}

Although the role of $\mathrm{K}^{+}$is still poorly investigated in mycorrhizal studies, it appears that plant $\mathrm{K}^{+}$nutrition is clearly improved by mycorrhization, especially under $\mathrm{K}^{+}$limiting conditions as, e.g., found in forest ecosystems. Moreover, this improvement could act on abiotic stress tolerance, $\mathrm{P}$ homeostasis maintenance, or exclusion of soil contaminants such as radiocaesium. Thanks to genome and transcriptome access, the dissection of molecular mechanisms involved will be unraveled in the coming years, strengthening our knowledge on the mycorrhizal contribution to plant $\mathrm{K}^{+}$nutrition.

\section{ACKNOWLEDGMENTS}

This work was supported by the ANR project "TRANSMUT" 2010 BLAN 1604 03. We would like to thank Cécile Fizames and Pierre-Marc Delaux for their help in phylogenetic analyses. Kevin Garcia was financially supported by a grant from the French Minister of Research and Technology. We are grateful to F. Martin and the Mycorrhizal Genomics Initiative consortium for access to unpublished genome data. The genome sequence data were produced by the U.S. Department of Energy Joint Genome Institute in collaboration with the user community. The JGI is supported by the Office of Science of the U.S. Department of Energy under Contract No. DE-AC02-05CH11231.

\section{REFERENCES}

Alemán, F., Nieves-Cordones, M., Martínez, V., and Rubio, F. (2011). Root $\mathrm{K}^{+}$ acquisition in plants: the Arabidopsis thaliana model. Plant Cell Physiol. 52, 1603-1612. doi: 10.1093/pcp/pcr096

Al-Karaki, G. N. (1998). Benefit, cost and water-use efficiency of arbuscular mycorrhizal durum wheat grown under drought stress. Mycorrhiza 8, 41-45. doi: 10.1007/s005720050209

Anschütz, U., Becker, D., and Shabala, S. (2014). Going beyond nutrition: regulation of potassium homoeostasis as a common denominator of plant adaptive responses to environment. J. Plant Physiol. 171, 670-687. doi: 10.1016/j.jplph. 2014.01.009

Asher, C. J., and Ozanne, P. G. (1967). Growth and potassium content of plants in solution cultures maintained at constant potassium concentrations. Soil Sci. 103, 155-161. doi: 10.1097/00010694-196703000-00002

Ashford, A. E., Vesk, P. A., Orlovich, D. A., Markovina, A. L., and Allaway, W. G. (1999). Dispersed polyphosphate in fungal vacuoles in Eucalyptus pilularis/Pisolithus tinctorius ectomycorrhizas. Fungal Genet. Biol. 28, 21-33. doi: 10.1006/fgbi.1999.1140

Bañuelos, M. A., Klein, R. D., Alexander-Bowman, S. J., and Rodríguez-Navarro, A. (1995). A potassium transporter of the yeast Schwanniomyces occidentalis homologous to the Kup system of Escherichia coli has a high concentrative capacity. EMBO J. 14, 3021-3027.

Baslam, M., Garmendia, I., and Goicoechea, N. (2013). The arbuscular mycorrhizal symbiosis can overcome reductions in yield and nutritional quality in greenhouse-lettuces cultivated at inappropriate growing seasons. Sci. Hortic. 164, 145-154. doi: 10.1016/j.scienta.2013.09.021

Benito, B., and Gonzalez-Guerrero, M. (2014). Unravelling potassium nutrition in ectomycorrhizal associations. New Phytol. 201, 707-709. doi: 10.1111/nph.12659

Benito, B., Haro, R., Amtmann, A., Cuin, T. A., and Dreyer, I. (2014). The twins $\mathrm{K}^{+}$and $\mathrm{Na}^{+}$in Plants. J. Plant Physiol. 171, 723-732. doi: 10.1016/j.jplph.2013. 10.014

Bossemeyer, D., Schlosser, A., and Bakker, E. P. (1989). Specific cesium transport via the Escherichia coli Kup (TrkD) $\mathrm{K}^{+}$uptake system. J. Bacteriol. 171, 2219-2221.

Broadley, M. R., and White, P. J. (2005). Plant Nutritional Genomics. Oxford: Blackwell Publishing; CRC Press.

Brunner, I., Frey, B., and Riesen, T. K. (1996). Influence of ectomycorrhization and cesium / potassium ratio on uptake and localization of cesium in Norway spruce seedlings. Tree Physiol. 16, 705-711. doi: 10.1093/treephys/16.8.705

Bücking, H., and Heyser, W. (1999). Elemental composition and function of polyphosphates in ectomycorrhizal fungi - an X-ray microanalytical study. Mycol. Res. 103, 31-39. doi: 10.1017/S0953756298006935

Casieri, L., Lahmidi, N. A., Doidy, J., Veneault-Fourrey, C., Migeon, A., Bonneau, L., et al. (2013). Biotrophic transportome in mutualistic plant fungal interactions. Mycorrhiza 23, 597-625. doi: 10.1007/s00572-013-0496-9

Corratgé, C., Zimmermann, S., Lambilliotte, R., Plassard, C., Marmeisse, R., Thibaud, J. B., et al. (2007). Molecular and functional characterization of a $\mathrm{Na}^{+}$$\mathrm{K}^{+}$transporter from the Trk family in the ectomycorrhizal fungus Hebeloma cylindrosporum. J. Biol. Chem. 282, 26057-26066. doi: 10.1074/jbc.M611613200

Corratgé-Faillie, C., Jabnoune, M., Zimmermann, S., Véry, A. A., Fizames, C., and Sentenac, H. (2010). Potassium and sodium transport in non-animal cells: the Trk/Ktr/HKT transporter family. Cell. Mol. Life Sci. 67, 2511-2532. doi: 10.1007/s00018-010-0317-7

Coskun, D., Britto, D. T., and Kronzucker, H. J. (2014). The physiology of channelmediated $\mathrm{K}^{+}$acquisition in roots of higher plants. Physiol. Plant. 151, 305-312. doi: $10.1111 / \mathrm{ppl} .12174$ 
Cumming, J. R. (1993). Growth and nutrition of nonmycorrhizal and mycorrhizal pitch pine (Pinus rigida) seedlings under phosphorus limitation. Tree Physiol. 13, 173-187. doi: 10.1093/treephys/13.2.173

Danielsen, L., and Polle, A. (in press). Poplar nutrition under drought as affected by ectomycorrhizal colonization. Environ. Exp. Botany. doi: 10.1016/j.envexpbot.2014.01.006

Delvaux, B., Kruyts, N., Maes, E., and Smolders, E. (2001). "Fate of radiocesium in soil and rhizosphere," in Trace Elements in the Rhizosphere, eds G. R. Gobran, W. W. Wenzel, and E. Lombi (Boca Raton, FL: CRC Press), 61-91.

Dominguez Nunez, J. A., Planelles Gonzalez, R., Rodriguez Barreal, J. A., and Saiz de Omenaca Gonzalez, J. A. (2008). The effect of Tuber melanosporum Vitt. mycorrhization on growth, nutrition, and water relations of Quercus petraea Liebl., Quercus faginea Lamk., and Pinus halepensis Mill. seedlings. New For. 2, 159-171. doi: 10.1007/s11056-007-9069-0

Dominguez Nunez, J. A., Selva Serrano, J., Rodriguez Barreal, J. A., and Saiz de Omenaca Gonzalez, J. A. (2006). The influence of mycorrhization with Tuber melanosporum in the afforestation of a Mediterranean site with Quercus ilex and Quercus faginea. For. Ecol. Manage. 231, 226-233. doi: 10.1016/j.foreco.2006.05.052

Drew, M. C., and Nye, P. H. (1969). The supply of nutrient ions by diffusion to plant roots in soil. II. The effect of root hairs on the uptake of potassium by roots of ryegrass (Lolium multiflorum). Plant Soil 31, 407-424. doi: 10.1007/BF01373813

Dreyer, I., and Uozumi, N. (2011). Potassium channels in plant cells. FEBS J. 278, 4293-4303. doi: 10.1111/j.1742-4658.2011.08371.x

El-Mesbahi, M. N., Azcón, R., Ruiz-Lozano, J. M., and Aroca, R. (2012). Plant potassium content modifies the effects of arbuscular mycorrhizal symbiosis on root hydraulic properties in maize plants. Mycorrhiza 22, 555-564. doi: 10.1007/s00572-012-0433-3

Estrada, B., Aroca, R., Maathuis, F. J. M., Barea, J. M., and Ruiz-Lozano, J. M. (2013). Arbuscular mycorrhizal fungi native from a Mediterranean saline area enhance maize tolerance to salinity through improved ion homeostasis. Plant Cell Environ. 36, 1771-1782. doi: 10.1111/pce.12082

Garcia, K., Delteil, A., Conéjéro, G., Becquer, A., Plassard, C., Sentenac, H., et al. (2014). Potassium nutrition of ectomycorrhizal Pinus pinaster: overexpression of the Hebeloma cylindrosporum HcTrk1 transporter affects the translocation of both $\mathrm{K}^{+}$and P in the host plant. New Phytol. 201, 951-960. doi: $10.1111 /$ nph.12603

Giri, B., Kapoor, R., and Mukerji, K. G. (2007). Improved tolerance of Acacia nilotica to salt stress by arbuscular mycorrhiza, Glomus fasciculatum, may be partly related to elevated $\mathrm{K}^{+} / \mathrm{Na}^{+}$ratios in root and shoot tissues. Microbial. Ecol. 54, 753-760. doi: 10.1007/s00248-007-9239-9

Grabov, A. (2007). Plant KT/KUP/HAK potassium transporters: single familymultiple functions. Ann. Bot. 99, 1035-1041. doi: 10.1093/aob/mcm066

Guether, M., Balestrini, R., Hannah, M., He, J., Udvardi, M. K., and Bonfante, P. (2009). Genome-wide reprogramming of regulatory networks, transport, cell wall and membrane biogenesis during arbuscular mycorrhizal symbiosis in Lotus japonicus. New Phytol. 182, 200-212. doi: 10.1111/j.14698137.2008.02725.x

Gyuricza, V., Declerck, S., and Dupré de Boulois, H. (2010a). Arbuscular mycorrhizal fungi decrease radiocesium accumulation in Medicago truncatula. J. Environ. Radioact. 101, 591-596. doi: 10.1016/j.jenvrad.2010.03.004

Gyuricza, V., Dupré de Boulois, H., and Declerck, S. (2010b). Effect of potassium and phosphorus on the transport of radiocesium by arbuscular mycorrhizal fungi. J. Environ. Radioact. 101, 482-487. doi: 10.1016/j.jenvrad.2008.04.002

Hammer, E. C., Nasr, H., Pallon, J., Olsson, P. A., and Wallander, H. (2011a). Elemental composition of arbuscular mycorrhizal fungi at high salinity. Mycorrhiza 21, 117-129. doi: 10.1007/s00572-010-0316-4

Hammer, E. C., Pallon, J., Wallander, H., and Olsson, P. A. (2011b). Tit for tat? A mycorrhizal fungus accumulates phosphorus under low plant carbon availability. FEMS Microbiol. Ecol. 76, 236-244. doi: 10.1111/j.1574-6941.2011.01043.x

Harley, J. L., and Smith, S. E. (1983). Mycorrhizal Symbiosis. London: Academic Press.

Hawkes, C. V., and Casper, B. B. (2002). Lateral root function and root overlap among mycorrhizal and nonmycorrhizal herbs in a Florida shrubland, measured using rubidium as a nutrient analog. Am. J. Bot. 89, 1289-1294. doi: 10.3732/ajb.89.8.1289

Hirrel, M. C., and Gerdemann, J. W. (1980). Improved growth of onion and bell pepper in saline soils by two vesicular-arbuscular mycorrhizal fungi. Soil Sci. Soc. Am. J. 44, 654-655. doi: 10.2136/sssaj1980.03615995004400030046x
Hirsch, R. E., Lewis, B. D., Spalding, E. P., and Sussman, M. R. (1998). A role for the AKT1 potassium channel in plant nutrition. Science 280, 918-921. doi: 10.1126/science.280.5365.918

Jan, L. Y., and Jan, Y. N. (1997). Cloned potassium channels from eukaryotes and prokaryotes. Annu. Rev. Neurosci. 20, 91-123. doi: 10.1146/annurev.neuro.20.1.91

Javot, H., Pumplin, N., and Harrison, M. J. (2007). Phosphate in the arbuscular mycorrhizal symbiosis: transport properties and regulatory roles. Plant Cell Environ. 30, 310-322. doi: 10.1111/j.1365-3040.2006.01617.x

Jentschke, G., Brandes, B., Kuhn, A. J., Schröder, W. H., and Godbold, D. L. (2001). Interdependence of phosphorus, nitrogen, potassium and magnesium translocation by the ectomycorrhizal fungus Paxillus involutus. New Phytol. 149, 327-337. doi: 10.1046/j.1469-8137.2001.00014.x

Jin, H. R., Liu, J., Liu, J., and Huang, X. W. (2012). Forms of nitrogen uptake, translocation, and transfer via arbuscular mycorrhizal fungi: a review. Sci. China Life Sci. 55, 474-482. doi: 10.1007/s11427-012-4330-y

Johansson, S. A. E., and Campbell, J. L. (1988). PIXE, a Novel Technique for Elemental Analysis. Chichester: John Wiley and Sons.

Joner, E. J., Roos, P., Jansa, J., Frossard, E., Leyval, C., and Jakobsen, I. (2004). No significant contribution of arbuscular mycorrhizal fungi to transfer of radiocesium from soil to plants. Appl. Environ. Microbiol. 70, 6512-6517. doi: 10.1128/AEM.70.11.6512-6517.2004

Jongbloed, R. H., Clement, J. M. A. M., and Borst-Pauwels, G. W. F. H. (1991). Kinetics of $\mathrm{NH}_{4}^{+}$and $\mathrm{K}^{+}$uptake by ectomycorrhizal fungi. Effect of $\mathrm{NH}_{4}^{+}$ on $\mathrm{K}^{+}$uptake. Physiol. Plant. 83, 427-432. doi: 10.1111/j.1399-3054.1991.tb0 0116.x

Jourand, P., Hannibal, L., Majorel, C., Mengant, S., Ducousso, M., and Lebrun, M. (2014). Ectomycorrhizal Pisolithus albus inoculation of Acacia spirorbis and Eucalyptus globulus grown in ultramafic topsoil enhances plant growth and mineral nutrition while limits metal uptake. J. Plant Physiol. 171, 164-172. doi: 10.1016/j.jplph.2013.10.011

Jung, N. C., and Tamai, Y. (2013). Polyphosphate (phytate) formation in Quercus acutissima-Scleroderma verrucosum ectomycorrhizae supplied with phosphate. J. Plant Interact. 8, 291-303. doi: 10.1080/17429145.2013.816789

Kaldorf, M., Kuhn, A. J., Schroder, W. H., Hildebrandt, U., and Bothe, H. (1999). Selective element deposits in maize colonized by a heavy metal tolerance conferring arbuscular mycorrhizal fungus. J. Plant Physiol. 154, 718-728. doi: 10.1016/S0176-1617(99)80250-8

Ketchum, K. A., Joiner, W. J., Sellers, A. J., Kaczmarek, L. K., and Goldstein, S. A. N. (1995). A new family of outwardly rectifying potassium channel proteins with 2 pore domains in tandem. Nature 376, 690-695. doi: 10.1038/376690a0

Ko, C. H., and Gaber, R. F. (1991). TRK1 and TRK2 encode structurally related K ${ }^{+}$ transporters in Saccharomyces cerevisiae. Mol. Cell. Biol. 11, 4266-4273.

Ladeyn, I., Plassard, C., and Staunton, S. (2008). Mycorrhizal association of maritime pine, Pinus pinaster, with Rhizopogon roseolus has contrasting effects on the uptake from soil and root-to-shoot transfer of ${ }^{137} \mathrm{Cs},{ }^{85} \mathrm{Sr}$ and ${ }^{95} \mathrm{mTc}$. J. Environ. Radioact. 99, 853-863. doi: 10.1016/j.jenvrad.2007.10.012

Lambilliotte, R., Cooke, R., Samson, D., Fizames, C., Gaymard, F., Plassard, C., et al. (2004). Large-scale identification of genes in the fungus Hebeloma cylindrosporum paves the way to molecular analyses of ectomycorrhizal symbiosis. New Phytol. 164, 505-513. doi: 10.1111/j.1469-8137.2004.01185.x

Leigh, R. A., and Wyn Jones, R. G. (1984). A hypothesis relating critical potassium concentrations for growth to the distribution and functions of this ion in the plant cell. New Phytol. 97, 1-13. doi: 10.1111/j.1469-8137.1984. tb04103.x

López, M. F., Dietz, S., Grunze, N., Bloschies, J., Weiss, M., and Nehls, U. (2008). The sugar porter gene family of Laccaria bicolor: function in ectomycorrhizal symbiosis and soil-growing hyphae. New Phytol. 180, 365-378. doi: 10.1111/j.1469-8137.2008.02539.x

Loth-Pereda, V., Orsini, E., Courty, P. E., Lota, F., Kohler, A., Diss, L., et al. (2011). Structure and expression profile of the phosphate Phtl transporter gene family in mycorrhizal Populus trichocarpa. Plant Physiol. 156, 2141-2154. doi: 10.1104/pp.111.180646

Martin, F., Aerts, A., Ahren, D., Brun, A., Danchin, E. G. J., Duchaussoy, F., et al. (2008). The genome of Laccaria bicolor provides insights into mycorrhizal symbiosis. Nature 452, 88-92. doi: 10.1038/nature06556

Martin, F., Kohler, A., Murat, C., Balestrini, R., Coutinho, P. M., Jaillon, O., et al. (2010). Périgord Black Truffle genome uncovers evolutionary origins and mechanisms of symbiosis. Nature 464, 1033-1038. doi: 10.1038/nature08867 
Müller, T., Avolio, M., Olivi, M., Benjdia, M., Rikirsch, E., Kasaras, A., et al. (2007). Nitrogen transport in the ectomycorrhiza association: the Hebeloma cylindrosporum-Pinus pinaster model. Phytochemistry 68, 41-51. doi: 10.1016/j.phytochem.2006.09.021

Nieves-Cordones, M., Alemán, F., Martínez, V., and Rubio, F. (2014). K ${ }^{+}$uptake in plant roots. The systems involved, their regulation and paralleles in other organisms. J. Plant Physiol. 171, 688-695. doi: 10.1016/j.jplph.2013.09.021

Ojala, J. C., Jarrell, W. M., and Menge, J. A. (1983). Influence of mycorrhizal fungi on the mineral nutrition and yield of onion in saline soil. Agron. J. 75, 255-259. doi: 10.2134/agronj1983.00021962007500020023x

Olsson, P. A., Hammer, E. C., Pallon, J., van Aarle, I. M., and Wallander, H. (2011). Elemental composition in vesicles of an arbuscular mycorrhizal fungus, as revealed by PIXE analysis. Fungal Biol. 115, 643-648. doi: 10.1016/j.funbio.2011.03.008

Olsson, P. A., Hammer, E. C., Wallander, H., and Pallon, J. (2008). Phosphorus availability influences elemental uptake in the mycorrhizal fungus Glomus intraradices, as revealed by particle-induced X-ray emission analysis. Appl. Environ. Microbiol. 74, 4144-4148. doi: 10.1128/AEM.00376-08

Orlovich, D. A., and Ashford, A. E. (1993). Polyphosphate granules are an artefact of specimen preparation in the ectomycorrhizal fungus Pisolithus tinctorius. Protoplasma 173, 91-102. doi: 10.1007/BF01378998

Pallon, J., Wallander, H., Hammer, E., Arteaga Marrero, N., Auzelyte, V., Elfman, M., et al. (2007). Symbiotic fungi that are essential for plant nutrient uptake investigated with NMP. Nucl. Instrum. Methods Phys. Res. B 260, 149-152. doi: 10.1016/j.nimb.2007.02.018

Papazian, D. M., Schwarz, T. L., Tempel, B. L., Jan, Y. N., and Jan, L. Y. (1987). Cloning of the genomic and complementary DNA from Shaker, a putative potassium channel gene from Drosophila. Science 237, 749-753. doi: $10.1126 /$ science. 2441470

Perner, H., Schwarz, D., Bruns, C., Mäder, P., and George, E. (2007). Effect of arbuscular mycorrhizal colonization and two levels of compost supply on nutrient uptake and flowering of pelargonium plants. Mycorrhiza 17, 469-474. doi: 10.1007/s00572-007-0116-7

Plassard, C., and Dell, B. (2010). Phosphorus nutrition of mycorrhizal trees. Tree Physiol. 30, 1129-1139. doi: 10.1093/treephys/tpq063

Porcel, R., and Ruiz-Lozano, J. M. (2004). Arbuscular mycorrhizal influence on leaf water potential, solute accumulation, and oxidative stress in soybean plants subjected to drought stress. J. Exp. Bot. 55, 1743-1750. doi: 10.1093/jxb/ erh188

Porras-Soriano, A., Soriano-Martín, M. L., Porras-Piedra, A., and Azcón, R. (2009). Arbuscular mycorrhizal fungi increased growth, nutrient uptake and tolerance to salinity in olive trees under nursery conditions. J. Plant Physiol. 66, 1350-1359. doi: 10.1016/j.jplph.2009.02.010

Rabie, G. G., and Almadini, A. M. (2005). Role of bioinoculants in development of salt-tolerance of Vicia faba plants under salinity stress. Afr. J. Biotechnol. 4, 210-222.

Rygiewicz, P. T., and Bledsoe, C. S. (1984). Mycorrhizal effects on potassium fluxes by northwest coniferous seedlings. Plant Physiol. 76, 918-923. doi: 10.1104/pp.76.4.918

Scheloske, S., Maetz, M., Schneider, T., Hildebrandt, U., Bothe, H., and Povh, B. (2004). Element distribution in mycorrhizal and nonmycorrhizal roots of the halophyte Aster tripolium determined by proton induced X-ray emission. Protoplasma 223, 183-189. doi: 10.1007/s00709-003-0027-1

Shabala, S., and Pottosin, I. (2014). Regulation of potassium transport in plants under hostile conditions: implications for abiotic and biotic stress tolerance. Physiol. Plant. 151, 257-279. doi: 10.1111/ppl.12165

Sharifi, M., Ghorbanli, M., and Ebrahimzadeh, H. (2007). Improved growth of salinity-stressed soybean after inoculation with pre-treated mycorrhizal fungi. J. Plant Physiol. 164, 1144-1151. doi: 10.1016/j.jplph.2006.06.016
Shin, R., and Adams, E. (2014). Transport, signalling and homeostasis of potassium and sodium in plants. J. Integr. Plant Biol. 56, 231-249. doi: 10.1111/jipb.12159

Smith, S. E., and Read, D. J. (2008). Mycorrhizal Symbiosis, 3rd Edn. New York, NY: Academic Press.

Smith, S. E., Smith, F. A., and Nicholas, D. J. D. (1981). Effects of endomcorrhizal infection on phosphate and cation uptake by Trifolium subterraneum. Plant Soil 63, 57-64. doi: 10.1007/BF02374257

Tamponnet, C., Martin-Garin, A., Gonze, M.A., Parekh, N., Vallejo, R., Sauras-Year, T., et al. (2008). An overview of BORIS: bioavailability of radionuclides in soils. J. Environ. Radioact. 99, 820-830. doi: 10.1016/j.jenvrad.2007.10.011

Turnau, K., Berger, A., Loewe, A., Einig, W., Hampp, R., Chalot, M., et al. (2001). Carbon dioxide concentration and nitrogen input affect the $\mathrm{C}$ and $\mathrm{N}$ storage pools in Amanita muscaria-Picea abies mycorrhizae. Tree Physiol. 21, 93-99. doi: 10.1093/treephys/21.2-3.93

Wallander, H., Johansson, L., and Pallon, J. (2002). PIXE analysis to estimate the elemental composition of ectomycorrhizal rhizomorphs grown in contact with different minerals in forest soil. FEMS Microbiol. Ecol. 39, 147-156. doi: 10.1111/j.1574-6941.2002.tb00916.x

Wallander, H., Mahmood, S., Hagerberg, D., Johansson, L., and Pallon, J. (2003). Elemental composition of ectomycorrhizal mycelia identified by PCR-RFLP analysis and grown in contact with apatite or wood ash in forest soil. FEMS Microbiol. Ecol. 44, 57-65. doi: 10.1111/j.1574-6941.2003.tb01090.x

Wallander, H., and Pallon, J. (2005). Temporal changes in the elemental composition of Rhizopogon rhizomorphs during colonization of patches with fresh organic matter or acid-washed sand. Mycologia 97, 295-303. doi: 10.3852/mycologia.97.2.295

Wang, B., and Qiu, Y. L. (2006). Phylogenetic distribution and evolution of mycorrhizas in land plants. Mycorrhiza 16, 299-363. doi: 10.1007/s00572-005-0033-6

Wang, Y., and Wu, W. H. (2013). Potassium transport and signaling in higher plants. Ann. Rev. Plant Biol. 64, 4.1-4.26. doi: 10.1146/annurev-arplant-050312120153

Wu, Q. S., and Xia, R. X. (2006). Arbuscular mycorrhizal fungi influence growth, osmotic adjustment and photosynthesis of citrus under wellwatered and water stress conditions. J. Plant Physiol. 163, 417-425. doi: 10.1016/j.jplph.2005.04.024

Zhang, H., Yin, W., and Xia, X. (2010). Shaker-like potassium channels in Populus, regulated by the CBL-CIPK signal transduction pathway, increase tolerance to low-K ${ }^{+}$stress. Plant Cell Rep. 29, 1007-1012. doi: 10.1007/s00299-010-0886-9

Zörb, C., Senbayram, M., and Peiter, E. (2014). Potassium in agriculture - Status and perspectives. J. Plant Physiol. 171, 656-669. doi: 10.1016/j.jplph.2013.08.008

Zuccarini, P., and Okurowska, P. (2008). Effects of mycorrhizal colonization and fertilization on growth and photosynthesis of sweet basil under salt stress. J. Plant Nutr. 31, 497-513. doi: 10.1080/01904160801895027

Conflict of Interest Statement: The authors declare that the research was conducted in the absence of any commercial or financial relationships that could be construed as a potential conflict of interest.

Received: 18 March 2014; accepted: 25 June 2014; published online: 17 July 2014. Citation: Garcia K and Zimmermann SD (2014) The role of mycorrhizal associations in plant potassium nutrition. Front. Plant Sci. 5:337. doi: 10.3389/fpls.2014.00337 This article was submitted to Plant Traffic and Transport, a section of the journal Frontiers in Plant Science.

Copyright (C) 2014 Garcia and Zimmermann. This is an open-access article distributed under the terms of the Creative Commons Attribution License (CC BY). The use, distribution or reproduction in other forums is permitted, provided the original author(s) or licensor are credited and that the original publication in this journal is cited, in accordance with accepted academic practice. No use, distribution or reproduction is permitted which does not comply with these terms. 